\title{
Diversity and abundance of scylla spp in mangrove habitat at Sungai Pinang village, Lingga
}

\begin{abstract}
This study examines the diversity and abundance of mangrove crabs (Scylla spp.), Which are carried out on mangrove ecosystems in Sungai Pinang village waters, East Lingga District, Lingga Regency, Riau Islands. Sampling was carried out at 8 locations, during the day and night, using quantitative descriptive methods. The yield of diversity and abundance of Scylla in this mangrove ecosystem is still low $\left(\mathrm{H}^{\prime}=0.315 ; \mathrm{N}=0.0011\right.$ individuals $\left./ \mathrm{m}^{2}\right)$. Area samples that are on high topography apparently contribute to the low level of diversity and abundance of Scylla spp. The recorded water quality includes temperature $28-30^{\circ} \mathrm{C}$, pH 5.50 to 6.58 , salinity $10.22-19.77 \%$, the tide height range is $8.50-72.42 \mathrm{~cm}$, and type of substrate a lot of mud. It turns out that the quality of these waters is suitable for the life of Scylla spp crabs.
\end{abstract}

Keywords: parameters of marine habitat, abundance, diversity, Scylla spp, sampling area
Volume 3 Issue 6 - 2019

\section{Eddiwan Kamaruddin, Yusni Ikhwan Siregar, Zulfan Saam, Sukendi}

Program in Environmental Sciences, Riau University, Indonesia

Correspondence: Eddiwan Kamaruddin, Program in Environmental Sciences, The Postgraduate Degree, Riau University, Campus Unri Gobah Jl Pattimura 9, Gobah, Pekanbaru, Riau, 28I25, Indonesia, Email eddiwa@lecturer.unri.ac.id

Received: October 01, 2019 | Published: November 07, 2019

\section{Introduction}

Mangrove forests are a habitat for many animals, such as mammals, amphibians, reptiles, birds, insects and various other biotas. Some species that live around mangrove roots, both on hard and soft substrate (mud) include mangrove crabs, shellfish and other invertebrate groups. ${ }^{1}$ Mangrove crabs (Scylla spp.) Belong to the family Portunidae which live in almost all coastal waters, especially on beaches that are overgrown with mangroves, shallow waters close to mangrove, estuary and muddy beaches that play a role in other ecological roles. ${ }^{2}$

Mangrove crabs are densely affected by the availability of natural food in the form of mangrove "serasah leaves" (decaying mangrove leaves) and mangroves. Mangrove River Pinang, Lingga Regency has been polluted due to mangrove charcoal industry activities. This is very interesting to be used as research because the density and abundance of mangrove crabs are very much affected by the quality of aquatic conditions. ${ }^{3}$ Some of the mangrove forest areas of Sungai Pinang Village is a mangrove conservation area, has a distinctive landscape or vegetation formation, and one type of vegetation in mangrove forest Sungai Pinang Village is the formation of mangrove forests that live in tidal areas, choppy calm, potentially grows in mangrove forests in Sungai Pinang Village.

Changes in the composition of mangrove vegetation due to illegal logging and natural disasters can cause zoning in crabs, thus affecting the composition of density and abundance of mangrove crabs. ${ }^{4}$ The purpose of this study was to determine the diversity, abundance, and influence of abiotic factors on the diversity and abundance of mangrove crabs (Scylla spp.) in mangrove forest habitat in Sungai Pinang village, Lingga Regency.

\section{Materials and methods}

Sampling locations and field data are mangrove forest habitat in Sungai Pinang village, Lingga Regency (Figure 1). The tools used in this study were Sony brand digital cameras (DSC-W170) 18.0, Garmin GPS (Global Positioning System) brand (60 CSx), zinc sampling markers area size $20 \mathrm{~cm} \times 30 \mathrm{~cm}$, plastic bags with a size of $10 \mathrm{~cm} \times 20 \mathrm{~cm}$, the study sample was mangrove crabs along the transect line in the plot of eight permanent sampling areas. The data obtained from this study are biotic data, namely the number and type of mangrove crabs (Scylla spp.), found in the mangrove forest area of Sungai Pinang village, Lingga Regency and Abiotic data in the form of measurements of temperature, $\mathrm{pH}$, salinity, substrate type, and tides the sea. After being identified, it was also determined the index of species diversity and abundance of mangrove crab species as follows.

\section{Analyzing of the diversity index of mangrove crab (scylla spp.)}

The diversity index value is obtained by processing data using Microsoft Excel and can be calculated using the formula from Shannon Wiener as follows:

$$
H^{\prime}=-\sum \frac{n i}{N} \ln \frac{n i}{N}
$$

$\mathrm{H}$ '= Shannon Wiener diversity index,

$\mathrm{ni}=\sum$ each species,

$\mathrm{N}=\sum$ total.

\section{Analyzing the abundance of mangrove crabs(scylla spp.)}

Abundance values are obtained by processing data using Microsoft Excel and using the following formula:

$$
H^{\prime}=-\sum(P i \ln P i)
$$

The level of diversity according to Krebs, 1986) is as follows:

$H^{\prime}<3.32=$ low diversity, 


$$
\begin{aligned}
& 3.32<\mathrm{H}^{\prime}<9.97=\text { moderate diversity, } \\
& \mathrm{H}^{\prime}>9.97=\text { high diversity. }
\end{aligned}
$$

\section{Analyzing the abundance of mangrove crabs(Scylla spp.)}

Abundance values are obtained by processing data using Microsoft Excel and using the following formula:

$$
N=\frac{n i}{A}
$$

$\mathrm{N}=$ Mangrove Crab Abundance (individual $/ \mathrm{m}^{2}$ ) $\mathrm{ni}=$ Number of individuals

$\mathrm{A}=$ Area $\left(\mathrm{m}^{2}\right)$

The linear regression equation is explained: $\mathrm{Y}=\mathrm{a}+\mathrm{bx}$

$\mathrm{Y}=$ predictive value (estimate) of the $\mathrm{Y}$ variable, based on the value of the selected variable $\mathrm{X}(\mathrm{F} 1)$

$$
\begin{aligned}
& \quad \mathrm{a}=\text { constant } \mathrm{Y} \text { or cut point is the approximate value for } \mathrm{Y} \text { when } \\
& \mathrm{X}=0 \\
& \mathrm{~b}=\text { Regression coefficient or slope of the line or change in mean at } \\
& \mathrm{Y} \text { for each unit of change in variable } \mathrm{X}(\mathrm{F} 1) \text {. }
\end{aligned}
$$

$\mathrm{X}=$ any value of the chosen independent variable.
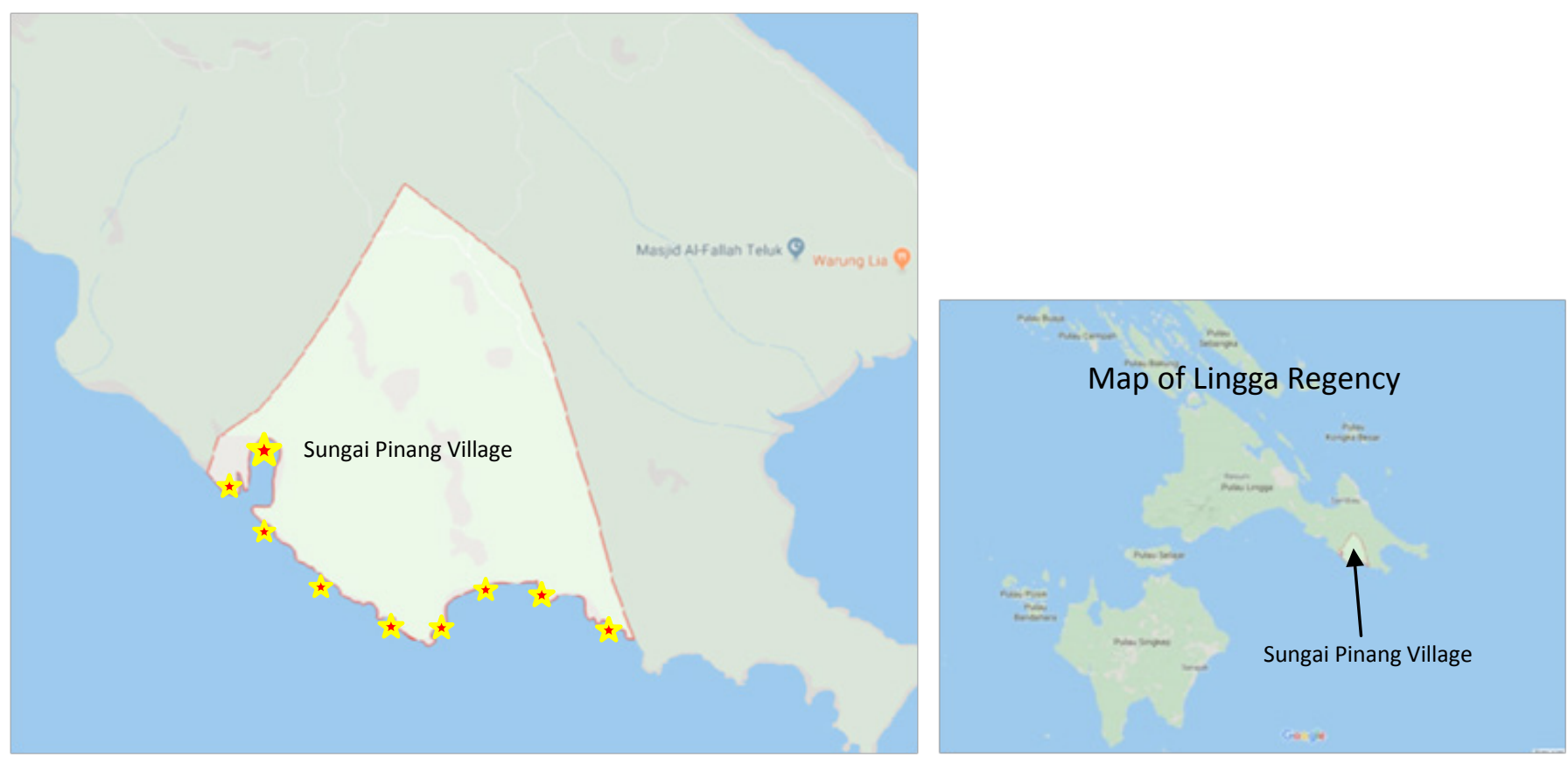

Figure I Map of Sungai Pinang village, East Lingga district, Lingga Regency, Riau Islands, Indonesia. Sampling area.

\section{Results and discussion}

\section{Diversity of mangrove crab (Scylla Spp.)}

The diversity index of mangrove crabs in each sampling area in the mangrove forest area of Sungai Pinang Village with an average of 0.315 . The level of diversity in each sampling area is low. While the diversity index of mangrove crabs in the Mergung River mangrove forest, Lingga Regency as a whole is 2.521 which is still classified as low as well because at the sampling area, the topography is higher and the tides do not reach the back, so the water disappears faster. According to Macintosh et al., ${ }^{5}$ the diversity value of crustaceans in the mangrove area in the Mahakam Delta belongs to the low category, which ranges from 0.80-3.0. The abundance of Mangrove Crab Types (Scylla spp.) from this study, found an average abundance of mangrove crabs 0.0011 individuals $/ \mathrm{m}^{2}$. While the highest abundance of mangrove crabs was found in the sampling area two, which was 0.0018 individuals $/ \mathrm{m}^{2}$, and the lowest abundance was in the sampling area of eight, namely 0.0006 individuals $/ \mathrm{m}^{2}$.

\section{Abiotic factors on the mangrove ecosystem}

Abiotic factors such as temperature measurements are carried out in soil, water and air. The results of water temperature measurements ranged from $30.89^{\circ} \mathrm{C}$ to $32.72^{\circ} \mathrm{C}$. From the results of measurements of water, soil and air temperatures in the mangrove ecosystem did not show significant differences between the stations. Thus the temperature factor in the mangrove ecosystem is not a factor that can affect the diversity and abundance of crabs.

Based on the value of the acidity $(\mathrm{pH})$, the Mangrove ecosystem in the Mergung River in Sungai Pinang Village found a very small different value, which is 5.51 to 6.68 , with an average $\mathrm{pH}$ of 6.34 . Tide measurements show the range of tidal heights from 8.60 to 72.52 $\mathrm{cm}$ with an average of 19.87 . Based on observations of salinity values, a difference between $10.25 \%$ to 19.79 it was found, with an average salinity of $3.68 \%$. Whereas, the C-organic content in, the substrate was found to vary in results in each area of the study sample. The range of organic matter content between stations is between $1.91 \%$ to 
$3.25 \%$, with an average of $2.57 \%$. The highest $\mathrm{C}$-organic content was found in sampling areas 7 and 8 . From the results of measurements of organic $\mathrm{C}$ in each sampling area apparently did not show a significant difference in sampling areas 1 to 8 . While substrate samples on the soil were analyzed at PT. Global Quality Analysis, Bogor, West Java. Test results at the Laboratory of PT. Global Quality Analytical, Bogor, West Java is matched with the Millar triangle to determine the substrate texture class.

\section{Results of linear regression analysis of abiotic factors on diversity of mangrove crab}

Simple linear regression analysis after PCA was performed to determine the effect of abiotic factor $(\mathrm{X})$ on diversity (Y1) and the effect of abiotic factor $(\mathrm{X})$ on the abundance of mangrove crabs following the following equation. A constant value a means that when the abiotic factor variable $(\mathrm{X})$ is zero or the diversity of mangrove crabs $(\mathrm{Y})$ is not influenced by abiotic factors, then the average diversity of mangrove crabs is 0.315 . While the regression coefficient $\mathrm{b}$ means that if the variable abiotic factor $(\mathrm{X})$ increases by one unit, then the diversity of mangrove crabs will increase by 0.317 . Based on the results of simple linear regression analysis, it can be concluded that the abiotic factor did not significantly influence the diversity of mangrove crabs.

\section{Results of linear regression analysis of abiotic factors against the abundance of mangrove crab}

The results of simple linear regression analysis using SPSS 20 software, obtained the regression model as follows. Constant value a means that when the abiotic factor variable $(\mathrm{X})$ is zero or the abundance of mangrove crabs (Y) is not affected by abiotic factors, then the average abundance of mangrove crabs is 0.001 . While the regression coefficient $\mathrm{b}$ means that if the abiotic factor variable $(\mathrm{X})$ increases by one unit, then the abundance of mangrove crabs will increase by 0.548 . Based on the results of simple linear regression analysis, it can be concluded that abiotic factors have no significant effect on the abundance of mangrove crabs. The influence of abiotic factors on this abundance has a significance level of 0.787 where the value is $>0.05$.

The results of the above calculation show that the value of the species diversity index ( $\left.\mathrm{H}^{\prime}\right)$ of mangrove crabs is 0.315 . High and low species diversity can be seen from the number of species found and abundance in nature. According to Huxham et al., ${ }^{6}$ if $\mathrm{H}^{\prime}=3.32$, the diversity of mangrove crabs is classified as low. The diversity of mangrove crabs was found at eight sampling areas of the study obtained 1 family of Portunidae, 1 genus and 2 species consisting of S. tranquebarica and S. olivacea.

The highest diversity index of mangrove crabs is in the sampling area of seven, which is $H^{\prime}=0.368$ because in sampling area seven the density of mangrove trees is quite high so that it produces a lot of leaf or mangrove leaves which is the most important intake for mangrove crabs. Odum et al., ${ }^{7}$ states that one of the factors that influence the diversity of mangrove crabs is the availability of natural foods derived from mangroves and the presence of mangrove leaves. The diversity index in the second order is in the sampling area two, namely $\mathrm{H}$ $'=0.362$. This is because in sampling the area of two Rhizophora mangrove plants found mostly from the front to the back sampling area with high density of mangroves so that the litter produced as a source of nutrition is quite high and due to tides touching to the back of the sampling area so that it can be a good reference for Scylla tranquibarica and Scylla olivacea for breeding.

According to Kristensen ${ }^{8}$ that mangrove crabs in the natural area of mangrove forests occupy are still influenced by tides. The third diversity index, $\mathrm{H}^{\mathrm{c}}=0.359$ is in the sampling area one, sampling area five and sampling area six because in the sampling area there is almost the same topography and composition of the mangrove vegetation. Tides do not touch until the back of the sampling area because the topography is higher than the sampling area 1 and 2 so that the tides are not long inundated and the water leaves the sampling area faster. Whereas in the last sequence is sampling eight areas with diversity index $H^{\prime}=0.281$, sampling area 3 is $H^{\prime}=0.60$, and sampling area 4 is $H^{\prime}=0.173$. This is because at the sampling area the location of the topography is higher and the tides do not reach the back so that the water disappears faster.

The diversity index value is an indicator of the many types of species in a particular area. Kathiresan et al., ${ }^{9}$ states that a community will not have a high diversity index value if there are one or more species in the community which has striking dominance far above most other species. ${ }^{10}$ In this study the number of each species is not the same and uneven, there are several species whose numbers are found in large numbers that cause the diversity of a small ecosystem. The uneven number of individuals in each species is related to the pattern of adaptation of each species and the availability of supporting habitats such as tides, food, and environmental conditions.

The calculation results show the abundance of mangrove crab types ranging from 0,0006 to 0,0018 individuals $/ \mathrm{m}^{2}$. The highest type of mangrove crab abundance is $S$. transquebarica which is equal to 0.72 . Abiotic factors measured in the morning and evening in this study included temperature, $\mathrm{pH}$, salinity, tides, and substrate. From the results of simple linear regression analysis, it can be seen that the effect of abiotic factors does not significantly influence the diversity of mangrove crabs because it has a significant level of 0.946 which means that the value is $>0.05$. Abiotic factors have no significant effect on the abundance of mangrove crabs because they have a significance level of 0.787 which means that the value is $>0.05$. The influence of abiotic factors such as the effect of rising temperatures causes an increase in the metabolism of the mangrove crab, because with increasing temperatures it will cause high evaporation, which can cause the soil substrate to dry up, as a result the mangrove crabs will be difficult to make marriages and skin changes, the mangrove crabs will many experience death. ${ }^{11}$ This will certainly reduce the amount of diversity and abundance of mangrove crabs.

For temperature measurements, in this study carried out on soil, water, and air, with almost the same measurement results in each sampling area. This can be caused by the influence of sunlight penetration, the presence or absence of shade by mangrove forests and weather conditions at the time of observation such as the intensity of sunlight that can affect temperature. Water temperature is in the range of $30.99-32.76^{\circ} \mathrm{C}$, soil temperature is in the range 28.39 $28.63^{\circ} \mathrm{C}$ while the air temperature is in the range of $28.32-29.04^{\circ} \mathrm{C}$. This temperature range is still very good for the life of mangrove crabs. According to Walton et al., ${ }^{12}$ mangrove crabs can grow quickly in waters with a temperature range of $28.8-36.0^{\circ} \mathrm{C}$. This shows that the average temperature in the Mangrove Forest on the Mergung River, Sungai Pinang Village can support the growth and development of mangrove crabs. 
The influence of acidity $(\mathrm{pH})$ has an important role as basic information about changes that occur in water, not only from the input of acidic or basic materials into the waters but also indirect changes in the metabolic activities of aquatic biota. High acidity can support the presence of decomposing organisms, to decompose organic matter that falls in the mangrove environment, so that the mangrove soil increases its acidity. Biadsanya, the higher the $\mathrm{pH}$ value, the faster the process of demineralization of organic material produced by litter material, and produce abundant organic material for the needs of mangrove crabs. The results of measurements of $\mathrm{pH}$ values in this study were in the range of 5.50 to 6.58 . The $\mathrm{pH}$ range obtained is included in both categories for growth and growth of mangrove crabs. Cannicci et al., ${ }^{13}$ stated that mangrove crabs can live in acidic conditions which are in mud substrate with an average $\mathrm{pH}$ of $6.5 .^{14}$

The salinity effect is needed in the life of mangrove crabs, ${ }^{15}$ through changes in the osmolality of water media which will determine the level of osmotic work (osmotic load) which will determine the survival rate and growth of crabs. Based on observations, salinity values range from 10.22 to $19.77 \%$ with an average of $3.66 \%$. Siple et al., ${ }^{16}$ states that mangrove crabs can live well at salinity $10-35 \%$. High and low salinity values in mangrove areas are largely determined by the influx of sea water during tides and fresh water from rivers. ${ }^{17}$ Based on the life cycle of crabs, in living their lives through various water conditions. When crabs first hatch, the ideal sea water temperature is $25-27^{\circ} \mathrm{C}$ and salinity $29-33 \%{ }^{18}$ The habits of crabs that tolerate salinity vary depending on the conditions of temperature and salinity of the waters when mangrove crabs move. ${ }^{19}$

The influence of the existence of tides shows that there is flooding of water in the ecosystem, which can have a direct impact on the presence of mangrove crabs. The results of seawater tide measurements indicate that the tide height range is $8.50-72.42 \mathrm{~cm}$ with an average of $33.93 \mathrm{~cm}$. Differences in sea tides are influenced by the topography of each sampling area that determines how much tide the sea can enter and inundate. This situation affects the state of the habitat and the adaptability of mangrove crabs. The sampling of areas 1, 2, 6 and 7 are lower so that high tides touching to the back of the sampling area and circulation of nutrients in the sampling area are high enough to be a good reference for mangrove crabs. The lowest tides occur at sampling areas 3, 4 and 8, due to their high location and even the surface shape of the land surface and water surface forming steep cliffs. This causes a small tide of sea water. The topography of each sampling area greatly determines how large the tide of seawater enters and submerges.

The influence of the substrate which contains a lot of mud is very suitable for the life of mangrove crabs, especially for carrying out marriages in the waters. In addition, the substrate is a place to release carapace crabs or skin changes. The way the crab releases is that the crab enters into a hole that has a soft substrate until the carapace hardens again. Hall et al., ${ }^{20}$ stated that the substrate around the mangrove forest strongly supports the life of mangrove crabs, especially to carry out their marriages and make skin changes in the waters.

Observation of the substrate in the mangrove Forest of Mergung River, Sungai Pinang Village includes observing the fraction of substrate and organic matter. Based on Millar Triangles, the substrate fraction is in the form of sand, dust, and clay with almost the same percentage in all sampling areas, resulting in the same texture class, namely salty clay. Salty clay has a rather slippery character, can form a ball in a dry state, is difficult to massage but is easily rolled and has high adhesion. This study also measured organic matter in the substrate, with results varying in each sampling area of the study. The range of organic matter content is between $1.92-3.26 \%$. The content of organic material in the substrate is needed by mangrove crabs for their food needs because the type of mangrove crabs take food not only from food contained in water, but also organic material contained in the soil. ${ }^{21,22}$

\section{Conclusion}

The diversity index of mangrove crabs in each sample in the mangrove ecosystem in Sungai Pinang village, $\mathrm{H}$ ' $=0.315$ which is classified as low diversity, the abundance of mangrove crabs (Scylla spp.) Of 0.0011 individuals $/ \mathrm{m}^{2}$ is also classified as low abundance. Abiotic factors in the form of temperature, $\mathrm{pH}$, salinity, tides, and substrate apparently did not have a significant effect $(p>0.05)$ on the diversity and abundance of mangrove crabs.

\section{Acknowledgments}

None.

\section{Conflicts of interest}

The author declares there are no conflicts of interest.

\section{References}

1. Bouillon S, Koedam N, Raman AV, et al. Primary producers of sustaining macro-invertebrates communities in intertidal mangrove forests. Oecologia. 2002;130(3):441-448.

2. Alfaro AC. Benthic macro-invertebrate community composition within a mangrove / seagrass estuary in northern New Zealand. Estuarine, Coastal and Shelf Science. 2006;66(1-2):97-110

3. Schaffelke B, Mellors J, Duke NC. Water quality in the Great Barrier Reef region: Responses of mangroves, seagrass and macroalgal communities. In Marine Pollution Bulletin. 2005;51(1-4):279-296.

4. Koenig CC, Coleman FC, Eklund AM, et al. Mangrove as essential nursery habitat for Goliath Grouper (Epinephelus itajara). In Bulletin of Marine Science. 2007;80(3):567-585.

5. Macintosh DJ, Ashton EC, Havanon S. Mangrove rehabilitation and intertidal biodiversity: A study in the Ranong mangrove ecosystem, Thailand. Estuarine, Coastal and Shelf Science. 2002;55:331-345.

6. Huxham M, Kimani E, Augley J. Mangrove fish: A comparison of community structures between forested and cleared habitats. Estuarine, Coastal and Shelf Science. 2004;60(4):637-647.

7. Odum WE, CM, Smith Thomas J. The Ecology of the Mangroves of South Florida: A community profile. 1982.

8. Kristensen E. Mangrove crabs as ecosystem engineers; with emphasis on sediment processes. Journal of Sea Research. 2008;59(1-2):30-43.

9. Kathiresan K, Bingham BL. Biology of mangroves and mangrove ecosystems. Advances in Marine Biology. 2001;40:81-251.

10. Ashton EC, Hogarth PJ, Macintosh DJ. A Comparison of the Chancellery Structure at Four Mangrove Locations under Different Management Systems along the Melaka Straits-Andaman Sea Coast of Malaysia and Thailand. Estuaries. 2003.

11. Skilleter GA, Warren S. Effects of habitat modification in mangrove on the structure of mollusc and crab assemblages. Journal of Experimental Marine Biology and Ecology. 2000;244(1):107-129. 
12. Walton ME, Le Vay L, Lebata JH, et al. Assessment of the effectiveness of mangrove rehabilitation using exploited and non-exploited indicator species. Biological Conservation. 2007;138(1-2):180-188.

13. Cannicci S, Bartolini F, Dahdouh Guebas F, et al. Effects of urban wastewater on crabs and mollusc assemblages in equatorial and subtropical mangroves of East Africa. Estuarine, Coastal and Shelf Science. 2009;84(3):305-317.

14. Kon K, Kurokura H, Tongnunui P. Do mangrove root structures function to shelter benthic macrofauna from predators? Journal of Experimental Marine Biology and Ecology. 2009;370(1-2):1-8.

15. Moser S, Macintosh D, Laoprasert S, et al. Population ecology of the mud crab Scylla olivacea: A mangrove ecosystem, Thailand in a Ranong study, with emphasis on juvenile recruitment and mortality. Fisheries Research. 2005;71(1):27-41.

16. Siple MC, Donahue MJ. Invasive mangrove removal and recovery: Food web effects across a chronosequence. Journal of Experimental Marine Biology and Ecology. 2013;448:128-135.
17. Lee SY. Ecological roles of grapsid crabs in mangrove ecosystems: a review. Marine and Freshwater Research. 1998;49(4):335-343.

18. Bandibas M, Hilomen V. Crab biodiversity under different management schemes of mangrove ecosystems. Global Journal of Environmental Science and Management. 2016;2(1):19-30.

19. Boeger WA, Pie MR, Ostrensky A, et al. Lethargic crab disease: Multidisciplinary evidence supports a mycotic etiology. Memorias Do Instituto Oswaldo Cruz. 2005;100(2):161-167.

20. Hall D, Lee SY, Meziane T. Fatty acids as trophic tracers in experimental estuarine food chain: Tracer transfers. Journal of Experimental Marine Biology and Ecology. 2006;336(1):42-53.

21. Etienne RS. A new sampling formula for neutral biodiversity. Ecology Letters. 2005;8(3):253-260.

22. Nagelkerken I, Blaber SJM, Bouillon S, et al. The habitat function of mangroves for terrestrial and marine fauna: A review. Aquatic Botany. 2008;89(2):155-185. 